\title{
Maternal Immunization of Mice with Group B Streptococcal Type III Polysaccharide-Beta C Protein Conjugate Elicits Protective Antibody to Multiple Serotypes
}

\author{
Lawrence C. Madoff, ${ }^{\star \star}$ Lawrence C. Paoletti, ${ }^{\star}$ Joseph Y. Tai, ${ }^{\mathbf{S}}$ and Dennis L. Kasper ${ }^{\star \star}$ \\ *Channing Laboratory, Brigham and Women's Hospital, and ${ }^{\ddagger}$ Division of Infectious Diseases, Beth Israel Hospital, Harvard Medical \\ School, Boston, Massachusetts 02115; and ${ }^{8}$ North American Vaccine, Inc., Beltsville, Maryland 20705
}

\begin{abstract}
Group B streptococcal infection is a major cause of neonatal mortality. Antibody to the capsular polysaccharide protects against invasive neonatal disease, but immunization with capsular polysaccharides fails to elicit protective antibody in many recipients. Conjugation of the polysaccharide to tetanus toxoid has been shown to increase immune response to the polysaccharide. In animal models, $\mathbf{C}$ proteins of group $B$ streptococci are also protective determinants. We examined the ability of the beta $\mathbf{C}$ protein to serve in the dual role of carrier for the polysaccharide and protective immunogen. Type III polysaccharide was covalently coupled to beta $\mathbf{C}$ protein by reductive amination. Immunization of rabbits with the polysaccharideprotein conjugate elicited high titers of antibody to both components, and the serum induced opsonophagocytic killing of type III, Ia/C, and Ib/C strains of group B streptococci. Female mice were immunized with the conjugate vaccine and then bred; $93 \%$ of neonatal pups born to these dams vaccinated with conjugate survived type III group B streptococcal challenge and $76 \%$ survived type Ia/C challenge, compared with $3 \%$ and $8 \%$ survival, respectively, in controls $(P<$ 0.001 ). The beta $C$ protein acted as an effective carrier for the type III polysaccharide while simultaneously inducing protective immunity against beta $\mathbf{C}$ protein-containing strains of group B streptococci. (J. Clin. Invest. 1994. 94:286-292.) Key words: Streptococcus agalactiae • vaccines, synthetic • antigens, bacterial - immunity, maternally acquired $\cdot$ streptococcal infections - carrier proteins
\end{abstract}

\section{Introduction}

Recent epidemiologic data confirm that group B streptococci (GBS $)^{1}$ remain the leading cause of serious neonatal infection (1). The rates of mortality and severe neurologic sequelae that result from this pathogen are unacceptably high, despite continued sensitivity to antibiotics and improved recognition and therapy. Each year in the U.S., several thousand infants become

Address correspondence to L. C. Madoff, Channing Laboratory, 180 Longwood Ave., Boston, MA 02115.

Received for publication 21 December 1993 and in revised form 24 February 1994.

1. Abbreviations used in this paper: GBS, group B streptococci; GCMS, gas chromatography-mass spectrometry; TT, tetanus toxoid.

J. Clin. Invest.

(C) The American Society for Clinical Investigation, Inc.

0021-9738/94/07/0286/07 \$2.00

Volume 94, July 1994, 286-292 seriously infected with this pathogen, and it is estimated that $15 \%$ succumb. In addition, the importance of GBS infections in adults has increasingly been recognized; cases in adults now account for fully half of invasive GBS disease. Immunization has been proposed as a strategy for the prevention of GBS infection (2). The capsular polysaccharides of the most prevalent serotypes causing disease have been the most widely explored antigens for this purpose $(3,4)$. While the polysaccharides alone are not sufficiently immunogenic to elicit protective antibodies in some recipients, glycoconjugate vaccines with the type-specific polysaccharides covalently linked to tetanus toxoid (TT) have shown high rates of protective immunization in experimental animals (5-10). Human trials of vaccines based on capsular polysaccharide-TT conjugates are now under way. Four capsular polysaccharides (serotypes Ia, Ib, II, and III) currently predominate among GBS strains causing invasive disease. Therefore, to be highly-effective, this type of GBS vaccine will need to be multivalent, containing each of the prevalent capsular serotypes. The widespread use of TT as both a vaccine and a carrier protein in conjugate vaccines may have drawbacks, including uncomfortable local reactions to immunization and suppression of responses to the hapten $(11,12)$. Thus, we wish to explore the use of alternative carrier proteins, which themselves may elicit protective immunity to GBS.

C proteins are surface-expressed antigens of GBS that also elicit protective immunity in experimental animals $(13,14)$. Although the alpha and beta $\mathrm{C}$ proteins are rarely found in type III strains of GBS, one or both of these antigens are expressed in most strains of other serotypes $(15,16)$. We and others have shown that both alpha and beta $C$ proteins are protective antigens for GBS in experimental animals (17-19). In addition to its capacity to elicit protective antibody, the beta $\mathrm{C}$ protein is known to bind human IgA to the surface of GBS $(20,21)$. Active immunization with the beta $C$ protein in female mice protects their offspring from lethal infection with strains that express this antigen (22). A glycoconjugate vaccine composed of the type III polysaccharide and C proteins could, in theory, protect against infection with the vast majority of GBS strains. If the $\mathrm{C}$ protein could act as both protective immunogen and carrier for the polysaccharide, it would obviate the need for TT as a carrier. However, little is known about the ability of the carrier protein in a glycoconjugate vaccine to elicit protective antibody responses. In this paper we describe the synthesis of a glycoconjugate vaccine composed of the beta $\mathrm{C}$ protein and the type III capsular polysaccharide. We demonstrate the ability of the vaccine to stimulate immune responses to both components and, via maternal immunization, to protect neonatal mice from lethal challenge with more than one serotype of GBS.

\section{Methods}

Bacterial strains. Strains were from the collection of the Channing Laboratory or were clinical isolates from hospitals associated with the 
Table I. Group B Streptococcal Serotype, Strain, and C Protein Phenotype

\begin{tabular}{|c|c|c|c|c|}
\hline \multirow{2}{*}{$\begin{array}{l}\text { Capsular } \\
\text { polysaccharide } \\
\text { serotype }\end{array}$} & \multirow[b]{2}{*}{ Strain } & \multicolumn{2}{|c|}{$\mathrm{C}$ protein } & \multirow[b]{2}{*}{ Reference } \\
\hline & & Alpha & Beta & \\
\hline \multirow{2}{*}{ Ia } & 515 & + & - & (19) \\
\hline & A909 & + & + & (13) \\
\hline \multirow[t]{4}{*}{$\mathrm{Ib}$} & H36B & + & + & (13) \\
\hline & S40 & + & + & (16) \\
\hline & S42 & - & + & (16, this paper) \\
\hline & $7357 b$ & - & + & (22) \\
\hline II & $18 \mathrm{RS} 21$ & - & - & (13) \\
\hline \multirow[t]{2}{*}{ III } & M781 & - & - & (25) \\
\hline & S23 & - & - & (16) \\
\hline
\end{tabular}

Baylor College of Medicine (generously provided by Dr. Carol J. Baker, Baylor College of Medicine, Houston, TX) and have been previously described (16). The serotypes of these strains are shown in Table I.

Beta $C$ protein. The beta $\mathrm{C}$ protein was generously provided by $\mathrm{Dr}$. Milan Blake (Rockefeller University, New York) and was produced by extraction into SDS from serotype Ib/C GBS strain H36B5, purified by gel filtration chromatography as described previously (20). Purity was assessed by observation of a single $130-\mathrm{kD}$ band on silver-stained SDSpolyacrylamide gel.

Oxidation of GBS type III polysaccharide. Type III GBS capsular polysaccharide ( $<200,000 M_{\mathrm{r}}$ ) was purified from GBS strain M781 as previously described (5). Aldehydes were formed on GBS type III polysaccharide by the conversion of a portion of the side chain sialic acid residues by limited oxidation with use of sodium periodate as described previously $(5,23)$. Briefly, $8.1 \mathrm{mg}$ of purified GBS type III polysaccharide, possessing $\sim 8 \mu$ moles of sialic acid, was combined with $2 \mu$ moles of freshly prepared sodium m-periodate (Sigma Chemical Co., St. Louis, MO) in a total volume of $0.5 \mathrm{ml}$ of water. The mixture was incubated at room temperature for $90 \mathrm{~min}$ in the dark. After incubation, excess periodate was consumed by the addition of ethylene glycol. Confirmation of the extent of oxidation was obtained by gas chromatography-mass spectrometry (GC-MS) of trimethylsilyl derivatives (5). The mixture was placed in dialysis tubing (Spectropor \#1; Spectrum Medical Industries, Inc., Los Angeles, CA) and dialyzed at $4^{\circ} \mathrm{C}$ against a total of 8 liters of water. The dialyzed sample was filtered $(0.45 \mu \mathrm{m})$ and dried by lyophilization.

Conjugation of GBS type III polysaccharide to GBS beta C protein. oxidized type III polysaccharide $(5.5 \mathrm{mg}$ ) was combined with $5 \mathrm{mg}$ of beta $C$ protein in a total volume of $0.5 \mathrm{ml}$ of phosphate buffered saline, pH 9.0-9.5. Sodium cyanoborohydride $(33 \mathrm{mg}$ ) was added and the mixture incubated at room temperature in the dark. To insure complete coupling an additional $12 \mathrm{mg}$ of sodium cyanoborohydride was added to the mixture after $6 \mathrm{~d}$ of incubation. The $\mathrm{pH}$ of the reaction was monitored by spotting a $2-\mu \mathrm{l}$ aliquot onto $\mathrm{pH}$ paper and maintained at 9.0-9.5 by the addition of $0.1 \mathrm{~N} \mathrm{NaOH}$. Conjugation failed to occur when the $\mathrm{pH}$ was not maintained above 8.0. The progress of the conjugation was monitored by gel filtration chromatography of samples as described previously (9). The conjugation was determined to be complete when the magnitude of the protein peak occurring at the void volume (indicative of a high- $M_{\mathrm{r}}$ complex) of a Superose 6 column (Pharmacia Fine Chemicals, Piscataway, NJ) remained constant. After $7 \mathrm{~d}$ of incubation, the conjugate vaccine was separated from uncoupled components with use of an S-300 HR (Pharmacia Fine Chemicals) gel filtration column $(2.6 \times 91.5 \mathrm{~cm})$. Fractions that eluted in the void volume were collected, and uncoupled aldehyde groups on the polysaccharide were reduced by the addition of $\sim 2 \mathrm{mg}$ of sodium borohydride. The reduction reaction was allowed to proceed for $1 \mathrm{~h}$ at room temperature. The GBS type III polysaccharide-beta $\mathrm{C}$ protein conjugate (III- $\beta$ ) was dialyzed at $4^{\circ} \mathrm{C}$ against a total of 16 liters of water and dried by lyophilization.

Biochemical analysis of III- $\beta$ vaccine. The carbohydrate and protein content of the III- $\beta$ vaccine were determined as previously described $(8,10)$.

Immunoblotting. Analysis of the vaccine was performed by western blotting, as previously described, with monoclonal antibody $3 \mathrm{E} 7$ specific for the beta $C$ protein (16), rabbit antiserum raised to type III polysaccharide conjugated to TT (5), or human myeloma $\operatorname{IgA}_{1}$ (graciously provided by Dr. Andrew Wright, Tufts University, Boston) (16).

Immunogenicity of III- $\beta$ vaccine in rabbits. The immune response to the III- $\beta$ vaccine was evaluated in rabbits. Two New Zealand White female rabbits (Millbrook Farms, Amherst, MA) each weighing 2-3 $\mathrm{kg}$ were immunized subcutaneously with $50 \mu \mathrm{g}$ of III- $\beta$ vaccine emulsified with complete Freund's adjuvant in a total volume of $1.0 \mathrm{ml}$. Booster doses of vaccine mixed with incomplete Freund's adjuvant were administered by the same route 21 and $41 \mathrm{~d}$ after the primary dose. A second set of three rabbits were immunized with uncoupled beta $C$ protein with use of the same route, adjuvant and schedule as with the conjugate vaccine. Serum was collected on days $0,21,41,55$, and 72 . Animals received food and water ad libitum.

ELISA. Antibodies to the type III GBS polysaccharide and to the beta $C$ protein were measured by ELISA as described previously ( 5 , 22). The titers were determined by serial twofold dilution (from a starting dilution of $1: 3,200$ ) as the greatest dilution with $\mathrm{A}_{405} \geq 0.2$ after $30 \mathrm{~min}$ of development.

ELISA inhibition. Relative binding affinities of antibodies to beta $\mathrm{C}$ protein in sera prepared to purified beta $C$ protein, either alone or as part of the conjugate vaccine, were assessed by inhibition of ELISA reactivity. Purified beta $C$ protein at concentrations ranging from 5 to $5,000 \mathrm{ng} / \mathrm{ml}$ was used to inhibit the binding of the antisera (anti-beta C protein diluted 1:400,000 and anti-III- $\beta$ diluted 1:200,000 to achieve similar ELISA reactivity) to plates coated with purified beta antigen. The absorbance values were plotted against $\log _{10}$ of beta $C$ protein concentration to generate inhibition curves.

Similarity of epitope expression of purified protein either alone or as part of a conjugate vaccine was assessed by determining their relative abilities to compete with the beta $\mathrm{C}$ protein expressed on intact GBS for binding to antiserum raised to the beta $C$ protein. ELISA plates were coated with type Ib/C GBS strain $7357 \mathrm{~b}$ as previously described (22). ELISA was performed with antiserum to the purified protein (diluted $1: 100,000$ ) incubated with either the III- $\beta$ conjugate or the beta $C$ protein ranging in protein concentration from 0.05 to $5 \mu \mathrm{g} / \mathrm{ml}$.

Relative binding affinities of the beta $C$ protein and the III- $\beta$ conjugate for human $\operatorname{IgA} A_{1}$ was measured by inhibition of binding of $\operatorname{Ig} A_{1}$ to ELISA plates coated with beta $C$ protein as follows: III- $\beta$ conjugate and unconjugated beta $C$ protein were serially diluted twofold from a starting protein concentration of $2.0 \mu \mathrm{g} / \mathrm{ml}$ and preincubated with an equal volume of human myeloma $\operatorname{IgA}(1.0 \mu \mathrm{g}$ in $50 \mu \mathrm{l})$ for $2 \mathrm{~h}$ at room temperature. The mixture $(100 \mu \mathrm{l})$ was transferred to ELISA plates coated with beta $C$ protein $(200 \mathrm{ng} /$ well) and incubated at room temperature for $1 \mathrm{~h}$. After washing, goat anti-human IgA conjugated to alkaline phosphatase (Tago, Inc., Burlingame, CA), diluted 1:1000, was added to the ELISA wells and incubated at $37^{\circ} \mathrm{C}$ for $1 \mathrm{~h}$.

The plates were washed and developed with commercial substrate (Sigma Chemical Co.). Percentage inhibition was calculated as $\left[\left(\mathrm{A}_{405}\right.\right.$ without inhibitor- $\mathrm{A}_{405}$ with inhibitor $) / \mathrm{A}_{405}$ without inhibitor $] \times 100$. The point of $50 \%$ inhibition was determined graphically.

Opsonophagocytic assay. The functional capacity of antibodies to C proteins of GBS was assessed by an opsonophagocytic assay (24) measuring in vitro killing of GBS. In brief, a $300-\mu$ l volume of human polymorphonuclear leukocytes $\left(\sim 3 \times 10^{6}\right.$ cells $)$ was mixed with the test GBS strain $\left(\sim 1.5 \times 10^{6} \mathrm{CFU}\right), 50 \mu \mathrm{l}$ of human serum (prepared for use as a complement source by absorption on ice for $30 \mathrm{~min}$ with GBS of homologous serotype), and $100 \mu$ l of antibody diluted 1:100. Pooled rabbit antisera to GBS type-specific polysaccharides conjugated to TT were used as the reference sera $(5,8,10)$. ELISA titers of these antisera to the homologous polysaccharides were as follows: Ia: 
200,000; Ib: 100,000; II: 100,000, III: 64,000 . Viable GBS cells were enumerated as 10 -fold dilutions on blood agar plates immediately and after a 60 -min incubation at $37^{\circ} \mathrm{C}$, and the difference was calculated as killing. The assay was repeated in the absence of antibody. The result is reported as the "log kill," which is the difference between killing with and without antibody for at least two determinations per strain.

Neonatal mouse protection. A neonatal mouse model of GBS infection was used to assess the protective efficacy of active immunization with the type III polysaccharide-beta $\mathrm{C}$ protein conjugate (III- $\beta$ ) vaccine (25). Female CD-1 mice 8 wk of age (Charles River Laboratories, Wilmington, MA) were vaccinated intraperitoneally with two $20-\mu \mathrm{g}$ doses of III- $\beta$ with and without alum (Alhydrogel, final concentration $1.5 \%$ ) as adjuvant at $21-\mathrm{d}$ intervals. Control dams received $10 \mu \mathrm{g}$ of beta C protein alone or $2 \mu \mathrm{g}$ type III polysaccharide-tetanus toxoid conjugate (III-TT) with alum by the same route and schedule. Mice were bred immediately after immunization and neonatal mouse pups (born $\sim 4$ wk later) were challenged with a beta $C$ protein-positive strain of GBS (A909, Ia/C alpha+, beta+) or with a type III strain (M781 type III C protein-negative). Pups were challenged with an inoculum of each strain lethal for 80-90\% of nonimmune pups of the same age $\left(5 \times 10^{4} \mathrm{CFU}\right.$ of GBS strain A909 and $5 \times 10^{6} \mathrm{CFU}$ of strain M781) within $48 \mathrm{~h}$ of birth. The challenge dose was administered intraperitoneally with a tuberculin syringe via a 27 -gauge needle in a total of $0.05 \mathrm{ml}$ of Todd-Hewitt broth. The number of pups that survived GBS infection was assessed $48 \mathrm{~h}$ after challenge and survival data compared using Fisher's exact test.

\section{Results}

Conjugation of GBS type III polysaccharide with GBS beta C protein. $47 \%$ of sialic acid residues on the type III polysaccharide were oxidized to $\mathrm{C} 8$ derivatives (5-acetamido-3,5-dideoxyD-galactosyloctulosonic acid) by treatment with sodium periodate as determined by GC-MS analysis of trimethylsilyl derivatives of the periodate-treated polysaccharide. The recovery of oxidized type III polysaccharide was $6.6 \mathrm{mg}$ or $81 \%$. Conjugation of type III polysaccharide with beta $\mathrm{C}$ protein resulted in the formation of a high- $M_{\mathrm{r}}\left(>1 \times 10^{6}\right)$ polymer. The recovery of type III-beta $C$ protein conjugate (III- $\beta$ ) vaccine was $3.9 \mathrm{mg}$ or $37 \%$. The III- $\beta$ vaccine was composed by weight of $44 \%$ protein and $56 \%$ carbohydrate. Further confirmation of conjugation was demonstrated by immunoblot with antiserum to type III polysaccharide and monoclonal antibody $3 E 7$ to beta $\mathrm{C}$ protein (not shown). By immunoblot reactivity, the $M_{\mathrm{r}}$ of the conjugate vaccine was $>200,000$ and uncoupled protein was not detected.

Immunogenicity of III- $\beta$ vaccine in rabbits. Rabbits immunized with III- $\beta$ conjugate developed ELISA antibody titers of $>100,000$ against the type III polysaccharide and $>400,000$ against the beta $\mathrm{C}$ protein (Table II). Rabbits immunized with unconjugated beta $C$ protein had beta-specific ELISA titers exceeding 600,000 . As expected the beta $C$ protein did not elicit antibodies to the type III polysaccharide.

Epitope expression on beta $C$ protein in conjugate vaccine. ELISA inhibition experiments were performed to assess the expression of epitopes on the beta $C$ protein within the conjugate vaccine. ELISA plates were coated with purified beta $C$ protein and tested against antisera raised to either the beta $C$ protein or the III- $\beta$ conjugate. Inhibition of antibody binding was achieved with increasing concentration of beta $C$ protein preincubated with diluted antisera. These inhibition curves were used to estimate the relative overall binding affinity to uncoupled beta $\mathrm{C}$ protein of antibodies in these two sera. The concentrations of beta $\mathrm{C}$ protein required to inhibit $50 \%$ of binding were similar:
$220 \mu \mathrm{g} / \mathrm{ml}$ for anti-beta $\mathrm{C}$ protein (uncoupled) and $175 \mu \mathrm{g} /$ $\mathrm{ml}$ for anti-III- $\beta$.

To compare the antigenicity of the beta $\mathrm{C}$ protein alone and coupled to the type III polysaccharide with that of the antigen as presented on intact bacteria, an ELISA inhibition experiment was performed with ELISA plates coated with intact beta-Cprotein-positive GBS. The competitive binding curves for the two antigens were essentially identical (not shown). Normalized for beta $\mathrm{C}$ protein content, the concentration required to inhibit $50 \%$ of binding was $1.15 \mu \mathrm{g} / \mathrm{ml}$ for the beta $\mathrm{C}$ protein and $0.92 \mu \mathrm{g} / \mathrm{ml}$ for the III- $\beta$ conjugate, thus demonstrating that conjugation with polysaccharide did not alter important beta antigenic epitopes in the conjugate.

IgA binding. IgA binding to the conjugate appears markedly diminished compared with the native protein on the immunoblot, even when five times the amount of conjugate was applied to the gel (Fig. 1). The protein-polysaccharide conjugate had a higher $M_{\mathrm{r}}$ than the unconjugated protein, barely entering the running gel. In the ELISA inhibition experiments (Fig. 2), $50 \%$ inhibition of $\operatorname{IgA} A_{1}$ binding occurred at a concentration of $3 \mu \mathrm{g} / \mathrm{ml}$ of uncoupled beta $\mathrm{C}$ protein and $>90 \%$ inhibition occurred at $25 \mu \mathrm{g} / \mathrm{ml}$, whereas less than $60 \%$ inhibition of $\operatorname{IgA}$ binding could be achieved by the conjugate at $200 \mu \mathrm{g} / \mathrm{ml}(=100$ $\mu \mathrm{g} / \mathrm{ml}$ beta $\mathrm{C}$ protein), the highest concentration tested.

Opsonophagocytosis of GBS strains by serum raised to the III- $\beta$ vaccine. Antiserum raised to the III- $\beta$ conjugate vaccine induced killing by human polymorphonuclear leukocytes (PMNs) in the opsonophagocytic assay against strains expressing either the beta $C$ protein or the type III capsular polysaccharide (Table III). The log reduction in CFU (minus the log reduction in CFU in the absence of antiserum) was comparable to that induced by antiserum raised to the III-TT vaccine. Strains that expressed neither the type III capsular polysaccharide nor the beta $\mathrm{C}$ protein (i.e., 515 serotype Ia/C alpha+ beta-, and 18RS21 serotype II) were not rendered susceptible to phagocytic killing by the III- $\beta$ conjugate vaccine-induced antiserum. One strain, S42 was previously reported to be beta $C$ protein negative (16) but exhibited a high level of opsonophagocytic killing with the anti-III- $\beta$ serum. On reexamination of the strain $S 42$ with monoclonal antibody to beta (3E7) by western blot, this strain was found, in fact, to express low levels of the beta C protein.

Neonatal mouse protection by immunization with III- $\beta$ vaccine. Active immunization with III- $\beta$ vaccine greatly enhanced survival of mice challenged either with type Ia/C (alpha+, beta+) strain A909 or with type III strain M781 (Table IV): $93 \%$ of neonatal pups whose mothers were immunized with the III- $\beta$ vaccine survived intraperitoneal challenge with type III GBS compared with $4 \%$ of those whose mothers were immunized with the beta $C$ protein alone $(P<0.001)$ and $83 \%$ of those whose mothers were immunized with III-TT (NS); $76 \%$ of neonatal mice whose mothers were immunized with the III$\beta$ vaccine survived challenge with the Ia/C strain of GBS compared with $3 \%$ of those whose mothers were immunized with III-TT $(P<0.001)$ and $62 \%$ of those whose mothers were immunized with beta $C$ protein alone (NS). While there was improved survival among the neonates of dams who received alum as an adjuvant with the vaccine, it was not statistically significant. Survival rates between litters within a test group were similar and each litter within a test group showed statistically significant increase in survival compared with the heterologous control $(P<0.02)$. 
Table II. Antibody Response in Rabbits Elicited by Immunization with III- $\beta$ Conjugate Vaccine or with beta C Protein Alone

\begin{tabular}{|c|c|c|c|c|c|c|c|}
\hline \multirow[b]{2}{*}{ Immunogen } & \multirow[b]{2}{*}{$n$} & \multirow[b]{2}{*}{ Coating antigen } & \multicolumn{5}{|c|}{ Geometric mean ELISA titer } \\
\hline & & & day 0 & 21 & 42 & 55 & 72 \\
\hline \multirow{2}{*}{ III- $\beta$ vaccine } & 2 & III PS & 3200 & 3200 & 12800 & 102400 & 144815 \\
\hline & & $\beta \mathrm{C}$ protein & 3200 & 3200 & 51200 & 144815 & 409600 \\
\hline \multirow[t]{2}{*}{ Beta $\mathrm{C}$ protein } & 3 & III PS & 3200 & 3200 & 3200 & 3200 & 3200 \\
\hline & & $\beta \mathrm{C}$ protein & 3200 & 25600 & 204800 & 409600 & 650200 \\
\hline
\end{tabular}

ELISA titers were determined for each rabbit at each time point. The geometric mean ELISA titer is shown. Rabbits immunized with either the III- $\beta$ or the beta $C$ protein developed high-titered antibody to beta. Those immunized with the beta $C$ protein alone demonstrated high antibody titers to the beta $\mathrm{C}$ protein but not to type III polysaccharide.

\section{Discussion}

The optimal design of conjugate vaccines remains an important goal. Protein-polysaccharide conjugate vaccines have been formulated to use a carrier protein to augment the immunogenicity of the polysaccharide antigen. In theory, the immune response to the polysaccharide is rendered $\mathrm{T}$ cell dependent and thus immune responsiveness increases with repeated immunization (26). The IgG response is enhanced, and the duration of immunity is prolonged. Previous vaccine formulations have generally used a carrier protein irrelevant to the primary disease for which the vaccine is designed. The currently available vaccines for Haemophilus influenzae type b (Hib), for example, use TT, diphtheria toxoid, or outer membrane protein of Neisseria meningitidis as carrier proteins (27).

The use of a limited number of carrier proteins for a growing number of conjugate vaccines has potential disadvantages. For example, the history of immunization to the carrier protein may affect the response to the polysaccharide antigen after immunization with a conjugate vaccine $(11,28,29)$. Recent immunization with TT appears to diminish the immune response to the

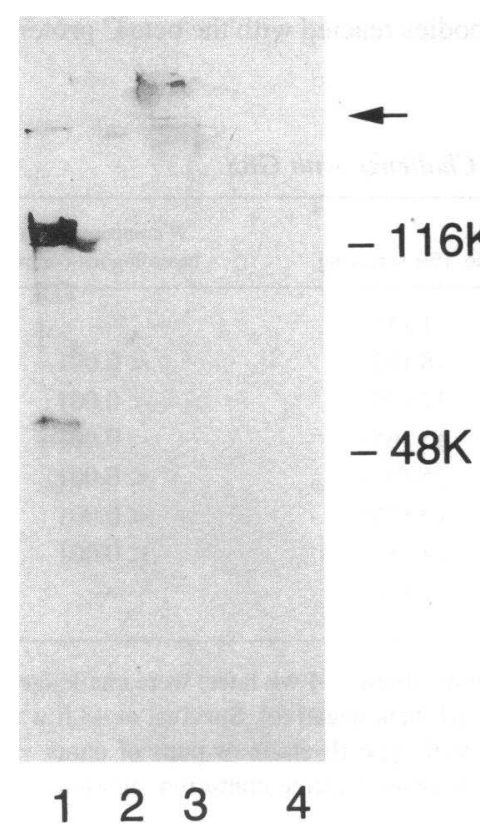

Figure 1. Immunoblot of beta $\mathrm{C}$ protein and group B streptococcal type III polysaccharide-beta $\mathrm{C}$ protein conjugate probed with human $\operatorname{Ig} \mathrm{A}_{1}$ at 10 $\mu \mathrm{g} / \mathrm{ml}$. Goat antiserum to human IgA labeled with alkaline phosphatase diluted $1: 1,000$ is used as the secondary antibody. Lane $l$ contains the unconjugated beta $\mathrm{C}$ protein $(1 \mu \mathrm{g})$; Lane 2 contains $2 \mu \mathrm{g}$; and lane 3 contains $10 \mu \mathrm{g}$ of the glycoconjugate. Lane 4 contains $10 \mu \mathrm{g}$ type III polysaccharide-tetanus toxoid conjugate (5) as a control. The immunoblot demonstrates reduction in binding to $\operatorname{IgA}$ after conjugation and increase in $M_{\mathrm{r}}$ after conjugation.
Hib polysaccharide in a Hib-TT conjugate (12). Repeated immunization with the same carrier protein may result in uncomfortable local reactions, thereby diminishing the palatability and perhaps the acceptance of these vaccines.

In the case of GBS, at least four capsular polysaccharides ( serotypes Ia, Ib, II, and III) currently predominate among GBS strains causing invasive disease, therefore, a polysaccharide based GBS vaccine will need to be multivalent containing each of the prevalent capsular serotypes. In such a multivalent vaccine, the quantity of TT required as a carrier may exceed the allowable amount for routine immunizations. Also, the widespread use of TT as both a vaccine and a carrier protein in this and other polysaccharide-protein conjugate vaccines may have drawbacks, including uncomfortable local reactions to immunization and suppression of responses to the hapten $(11,12)$.

In contrast, the use of a protective antigen from the target organism may enhance the effectiveness of a conjugate vaccine by eliciting antibodies that are themselves protective. The pro-

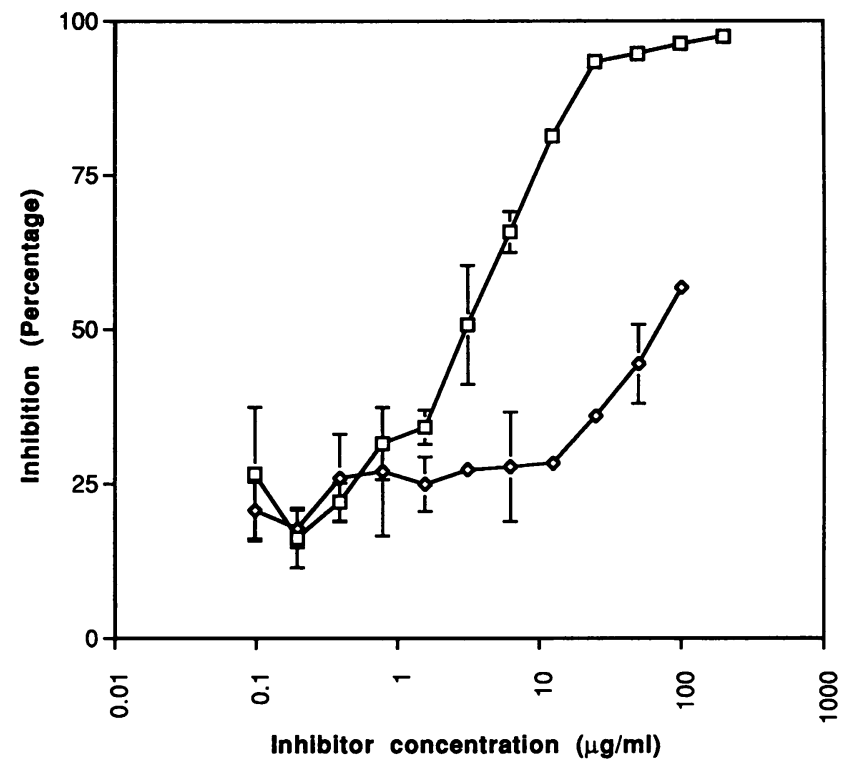

Figure 2. ELISA inhibition of human $\operatorname{Ig} \mathrm{A}_{1}$ binding to plates coated with beta $C$ protein by beta $C$ protein $(\square)$ or by III-beta conjugate $(\diamond)$ (normalized for the beta $\mathrm{C}$ protein content of each). Points are mean of two determinations and standard deviation of the mean is plotted. The curves demonstrate a loss of IgA binding capacity by the conjugate compared with the native protein. 
Table III. In Vitro Opsonophagocytic Killing of GBS by Human Peripheral Blood Leukocytes

\begin{tabular}{cccc}
\hline & & \multicolumn{2}{c}{ Reduction in GBS CFU $\left(\log _{10}\right)$} \\
\cline { 3 - 4 } $\begin{array}{c}\text { GBS } \\
\text { strain }\end{array}$ & $\begin{array}{c}\text { Beta C } \\
\text { protein }\end{array}$ & $\begin{array}{c}\text { Homologous } \\
\text { reference sera }\end{array}$ & anti-III- $\beta$ \\
\hline Type Ia & & & \\
A909 & + & 1.80 & 1.16 \\
515 & - & 1.57 & 0.08 \\
Type Ib & & & \\
H36B & + & 0.80 & 1.78 \\
S40 & + & 0.50 & 1.18 \\
S42 & + & 0.82 & 1.16 \\
Type II & & & \\
& & & -0.13 \\
18RS21 & - & 0.92 & \\
Type III & & & 0.93 \\
M781 & - & 0.69 & \\
S23 & - & 0.84 & \\
\hline
\end{tabular}

Group B streptococci were grown to mid-log phase and incubated with rabbit antiserum ( $1 \%$ final concentration), human serum as a source of complement, and human polymorphonuclear leukocytes. Organisms were enumerated by dilution on blood agar plates immediately and after $60 \mathrm{~min}$. The result (mean of duplicate determinations) is expressed as the $\log _{10}$ reduction in CFU. Rabbit antisera to group B streptococcal type-specific polysaccharides covalently conjugated to tetanus toxoid were used as the reference sera $(5,8,10)$. The experiment demonstrates that strains which express either the type III polysaccharide or the beta $C$ protein are rendered susceptible to killing by anti-III- $\beta$ serum.

tective level of antibody elicited by the vaccine may increase if both antigens are present on the same pathogen. In addition, the carrier protein may expand the coverage of the vaccine to include organisms that possess a different capsular polysaccharide.

Most vaccines currently under study for the prevention of GBS infection are based on the capsular polysaccharide antigens
$(5,7,8,10,30)$. The most prevalent type-specific polysaccharides are well characterized and have been shown to be critical targets for specific immunity in preventing neonatal GBS infection $(3,4,31)$. These antigens have been safely used to immunize pregnant women, and type-specific antibody has been shown to cross the placenta at levels protective to newborns (4). Although the polysaccharides are themselves not adequately immunogenic in some recipients, conjugate vaccines composed of type-specific polysaccharide conjugated to tetanus toxoid have been shown to elicit protective antibodies in animals and are currently in human trials $(5,8)$.

In addition to the capsular polysaccharides, GBS possess protective surface protein antigens including the $\mathrm{C}$ proteins alpha and beta present mainly in non-type III strains $(15,16)$, the Rib protein present mainly in strains of capsular serotypes II and III (32), and the R proteins found in several capsular types $(33,34)$. We have chosen to study one of these surface proteins for its use as both carrier and immunogen in a conjugate vaccine. The beta $C$ protein elicits maternal antibodies that protect neonatal mice from lethal challenge with GBS which express the beta $C$ protein (22). We now demonstrate that the beta $C$ protein can be covalently coupled to the type III GBS polysaccharide through limited oxidation of polysaccharide sialic acid residues followed by reductive amination. Conjugation by this method which is thought to occur mainly at lysine residues of the protein component (35), may have been facilitated by the extremely lysine-rich nature of the beta $\mathrm{C}$ protein, which has 156 lysine residues out of 1,134 amino acids $(36,37)$. Conjugation of these two molecules required careful titration of $\mathrm{pH}$ because of the highly acidic nature of both the beta $\mathrm{C}$ protein and the type III polysaccharide $(36,37)$.

Immunization of rabbits with the III- $\beta$ conjugate vaccine elicited high antibody titers against the type III polysaccharide, whereas the type III polysaccharide alone has been shown to be nonimmunogenic in rabbits (5). Thus, the beta $C$ protein functions as an effective carrier protein in this vaccine presumably by allowing the development of $\mathrm{T}$ cell-dependent immunity to the polysaccharide. The conjugate vaccine also elicited antibodies to beta $\mathrm{C}$ protein at titers comparable with those elicited by the beta $\mathrm{C}$ protein alone (22). Conjugate vaccineinduced beta $\mathrm{C}$ protein antibodies reacted with the beta $\mathrm{C}$ protein

Table IV. Neonatal Mouse Survival after Maternal Immunization with III- $\beta$ Conjugate Vaccine and Challenge with GBS

\begin{tabular}{|c|c|c|c|c|c|c|}
\hline Dams immunized with & Adjuvant & $\begin{array}{l}\text { Challenge strain } \\
\text { (serotype) }\end{array}$ & No. dams & No. pups & No. (\%) surviving & $\begin{array}{l}P \text { compared with } \\
\text { heterologous control }\end{array}$ \\
\hline$\beta \mathrm{C}$-protein alone & None & M781 (III) & 2 & 26 & $1(4)$ & - \\
\hline$\beta \mathrm{C}$-protein alone & None & A909 (Ia/C) & 2 & 29 & $18(62)$ & $<0.001$ \\
\hline III- $\beta$ vaccine & None & M781 (III) & 2 & 24 & $17(70)$ & $<0.001$ \\
\hline III- $\beta$ vaccine & None & A909 (Ia/C) & 2 & 23 & $15(65)$ & $<0.001$ \\
\hline III- $\beta$ vaccine & Alum & M781 (III) & 2 & 27 & $25(93)$ & $<0.001$ \\
\hline III- $\beta$ vaccine & Alum & A909 (Ia/C) & 2 & 25 & $19(76)$ & $<0.001$ \\
\hline III-TT & Alum & M781 (III) & 3 & 29 & $24(83)$ & $<0.001$ \\
\hline III-TT & Alum & A909 (Ia/C) & 3 & 37 & $1(3)$ & - \\
\hline
\end{tabular}

Female mice were immunized with the agent shown. Mice were bred after immunization and their newborn pups (born $\sim 4$ wk later) were challenged with $90 \%$ lethal doses of either group B streptococcal strain A909 (type Ia/C, beta positive) or M781 (type III, beta negative). Survival at $48 \mathrm{~h}$ was compared with heterologous controls (i.e., pups of dams immunized with beta $\mathrm{C}$ protein alone challenged with type III strain or pups of dams immunized with III-TT challenged with Ia/C beta positive strain). Maternal immunization with the III- $\beta$ conjugate vaccine conferred significant protection against neonatal challenge with both group B streptococcal serotypes. 
with similar relative binding affinities (as measured by ELISA inhibition) to that elicited by the beta $\mathrm{C}$ protein alone. In addition, whether uncoupled or coupled to the polysaccharide, the beta $\mathrm{C}$ protein competed with beta $\mathrm{C}$ protein antigen on whole bacteria for binding to beta $\mathrm{C}$ protein-specific sera, thus demonstrating that conjugation to the polysaccharide did not alter important antigenic epitopes on the protein. The biological significance of the preserved antigenicity of the beta $C$ protein after coupling is confirmed by the fact that the antiserum to the conjugate is highly opsonic for strains expressing the beta $\mathrm{C}$ protein. It appears as if protective antigenic epitopes remained available to the immune system despite covalent linkage of the protein to the polysaccharide.

Antibodies to both components of the III- $\beta$ conjugate vaccine were shown to be functionally active in an opsonophagocytic assay, i.e., capable of mediating complement-dependent killing of GBS by PMNs. Moreover, the rabbit antibodies induced killing of both type III strains and strains of different capsular serotypes that expressed the beta $\mathrm{C}$ protein. Thus this is an example of a carrier protein extending the spectrum of coverage of a conjugate vaccine.

In the neonatal mouse model of protection, active immunization of female mice with the III- $\beta$ vaccine protected the offspring of the mice against challenge with either a type III GBS strain or a Ia/C GBS strain. This result implies the generation of protective type-specific antibodies to both components and the transplacental passage of these antibodies to the pups. Levels of protection were comparable to those elicited by the beta $\mathrm{C}$ protein alone for the Ia/C strain and those elicited by the III-TT conjugate vaccine. Whereas a III-TT vaccine construct provides protection against GBS type III serotypes, the III- $\beta$ vaccine has expanded the coverage to include not only type III GBS strains but other non-type III GBS serotypes as well. The use of alum as an adjuvant did not alter the survival of pups significantly, although there was a trend toward greater survival among pups whose mothers received vaccine with adjuvant. Flores et al. (38) showed that some parturient women colonized with GBS possess naturally occurring antibody to the beta $C$ protein and that there was concordance between ELISA titers of antibody in these women and their neonates suggesting transplacental passage of beta-specific antibody in humans.

The beta $\mathrm{C}$ protein binds specifically to human $\operatorname{IgA}$ via a nonimmune mechanism (20). One theoretical drawback to the use of the beta $C$ protein in a conjugate vaccine is the ability of the vaccine to bind to human IgA. The consequences of this binding are not clear, and there are no unusual immune phenomena associated with infection with GBS strains that express these proteins (or other bacteria that express immunoglobulin binding proteins). Conjugation to the polysaccharide appeared to diminish greatly the affinity of the protein for IgA binding. However, the immunoblot of the conjugate to human IgA demonstrated some detectable binding, even after conjugation. The diminution of binding may occur via steric interference with the IgA binding site, through partial denaturation of the protein, or by binding to lysine residues in or adjacent to the active site. It may be possible to eliminate this theoretical concern associated with use of the beta $\mathrm{C}$ protein by fully eliminating $\operatorname{IgA}$ binding through alteration of the nature of the conjugation, for example, by increasing the percentage of sialic acid residues that are oxidized and thus increasing the degree of cross-linking in the glycoconjugate. Alternatively, the beta $\mathrm{C}$ protein could be modified, for example, by mutagenesis, to eliminate $\operatorname{IgA}$ binding. Finally non-IgA binding variants of the beta $\mathrm{C}$ protein have been described that, if fully immunogenic and protective, may represent alternative carrier proteins (39). Despite this alteration in functional activity, conjugation did not appear to alter antigenic or immunogenic properties of the protein.

The beta $C$ protein is found in $\sim 40 \%$ of non-type III GBS clinical isolates (15). The alpha $\mathrm{C}$ protein, which is also a protective determinant, is present in approximately half of all clinical isolates and in more than $90 \%$ of non-type III isolates (15). Thus, a type III polysaccharide-alpha $\mathrm{C}$ protein conjugate vaccine would theoretically offer nearly universal coverage of GBS isolates with a single vaccine construct. We are currently exploring the use of this protein for such purposes.

The conjugation of the type III GBS capsular polysaccharide to the beta $C$ protein from the same species of organism demonstrated that specific, protective immunity can be elicited to both components of the conjugate vaccine and that the protein component can act as both carrier and immunogen. This work lays the foundation for further studies of this novel type of vaccine and for further optimization of glycoconjugate vaccines.

\section{Acknowledgments}

GC-MS analysis was performed by R. Pon and H. Jennings, National Research Council, Ottawa. The superb technical assistance of Elizabeth W. Gong and Kenneth Johnson is acknowledged. The contents of this publication do not necessarily reflect the views or policies of the Department of Health and Human Services, nor does mention of trade names, commercial products, or organizations imply endorsement by the U.S. government.

This research was supported in part by Public Health Service Contract NO1 AI25152 "Prevention of group B streptococcal infection in neonatal and infant populations" and National Institutes of Health grants AI00981, AI08222, and AI23339.

\section{References}

1. Farley, M. M., R. C. Harvey, T. Stull, J. D. Smith, A. Schuchat, J. D. Wenger, and D. S. Stephens. 1993. A population-based assessment of invasive disease due to group B Streptococcus in nonpregnant adults. N. Engl. J. Med. 328:1807-1811.

2. Baker, C. J., and D. L. Kasper. 1985. Vaccination as a measure for prevention of neonatal GBS infection. Antibiot. Chemother. 35:281-290.

3. Baker, C. J., D. L. Kasper, M. S. Edwards, and G. Schiffman. 1980. Influence of preimmunization antibody levels on the specificity of the immune response to related polysaccharide antigens. N. Engl. J. Med. 303:173-178.

4. Baker, C. J., M. A. Rench, M. S. Edwards, R. J. Carpenter, B. M. Hays, and D. L. Kasper. 1988. Immunization of pregnant women with a polysaccharide vaccine of group B Streptococcus. N. Engl. J. Med. 319:1180-1220.

5. Wessels, M. R., L. C. Paoletti, D. L. Kasper, J. L. DiFabio, F. Michon, K. Holme, and H. J. Jennings. 1990. Immunogenicity in animals of a polysaccharideprotein conjugate vaccine against type III group B Streptococcus. J. Clin. Invest. $86: 1428-1433$

6. Baker, C. J., M. A. Rench, and D. L. Kasper. 1990. Response to type III polysaccharide in women whose infants have had invasive group B streptococcal infection. N. Engl. J. Med. 322:1857-1860.

7. Lagergard, T., J. Shiloach, J. B. Robbins, and R. Schneerson. 1990. Synthesis and immunological properties of conjugates composed of group B streptococcus type III capsular polysaccharide covalently bound to tetanus toxoid. Infect. Immun. 58:687-694.

8. Paoletti, L. C., M. R. Wessels, F. Michon, J. DiFabio, H. J. Jennings, and D. L. Kasper. 1992. Group B Streptococcus type II polysaccharide-tetanus toxoid conjugate vaccine. Infect. Immun. 60:4009-4014.

9. Paoletti, L. C., M. R. Wessels, F. Michon, H. J. Jennings, and D. L. Kasper. 1992. Group B Streptococcus type III glycoconjugate vaccines. Trends Glycosci. Glycotechnol. 4:269-278.

10. Wessels, M. R., L. C. Paoletti, A. K. Rodewald, F. Michon, J. DiFabio, H. J. Jennings, and D. L. Kasper. 1993. Stimulation of protective antibodies 
against type Ia and Ib group B streptococci by a type Ia polysaccharide-tetanus toxoid conjugate vaccine. Infect. Immun. 61:4760-4766.

11. Herzenberg, L. A., and T. Tokuhisa. 1982. Epitope-specific regulation. I. Carrier-specific induction of suppression for IgG anti-hapten antibody responses. J. Exp. Med. 155:1730-1740.

12. Barington, T., M. Skettrup, L. Juul, and C. Heilmann. 1993. Non-epitopespecific suppression of the antibody response to Haemophilus influenzae type $b$ conjugate vaccines by preimmunization with vaccine components. Infect. Immun. 61:432-438.

13. Lancefield, R. C., M. McCarty, and W. N. Everly. 1975. Multiple mouseprotective antibodies directed against group B streptococci. Special reference to antibodies effective against protein antigens. J. Exp. Med. 142:165-179.

14. Wilkinson, H. W., and R. G. Eagon. 1971. Type-specific antigens of group B streptococcus. Infect. Immun. 4:596-604.

15. Johnson, D. R., and P. Ferrieri. 1984. Group B streptococcal Ibc protein antigen: distribution of two determinants in wild-type strains of common serotypes. J. Clin. Microbiol. 19:506-510.

16. Madoff, L. C., S. Hori, J. L. Michel, C. J. Baker, and D. L. Kasper. 1991. Phenotypic diversity in the alpha C protein of group B streptococcus. Infect. Immun. 59:2638-2644.

17. Madoff, L. C., J. L. Michel, and D. L. Kasper. 1991. A monoclonal antibody identifies a protective $\mathrm{C}$-protein alpha-antigen epitope in group B streptococci. Infect. Immun. 59:204-210.

18. Bevanger, L., and A. I. Naess. 1985. Mouse-protective antibodies against the Ibc proteins of group B streptococci. Acta. Pathol. Microbiol. Immunol. Scand. Sect. B Microbiol. 93:121-124.

19. Michel, J. L., L. C. Madoff, D. E. Kling, D. L. Kasper, and F. M. Ausubel. 1991. Cloned alpha and beta C-protein antigens of group B streptococci elicit protective immunity. Infect. Immun. 59:2023-2028.

20. Russell-Jones, G. J., E. C. Gotschlich, and M. S. Blake. 1984. A surface receptor specific for human IgA on group B streptococci possessing the Ibc protein antigen. J. Exp. Med. 160:1467-1475.

21. Anthony, B. F., N. F. Concepcion, S. M. Puentes, and N. R. Payne. 1990. Nonimmune binding of human immunoglobulin A to type II group B streptococci. Infect. Immun. 58:1789-1795.

22. Madoff, L. C., J. L. Michel, E. W. Gong, A. K. Rodewald, and D. L. Kasper. 1992. Protection of neonatal mice from group B streptococcal infection by maternal immunization with beta $C$ protein. Infect. Immun. 60:4989-4994.

23. Jennings, H. J., and C. Lugowski. 1981. Immunochemistry of groups A, $\mathrm{B}$, and $\mathrm{C}$ meningococcal polysaccharide-tetanus toxoid conjugates. J. Immunol. 127:1011-1018.

24. Baltimore, R. S., D. L. Kasper, C. J. Baker, and D. K. Goroff. 1977. Antigenic specificity of opsonophagocytic antibodies in rabbit anti-sera to group B streptococci. J. Immunol. 118:673-678.

25. Rodewald, A. K., A. B. Onderdonk, H. B. Warren, and D. L. Kasper. 1992. Neonatal mouse model of group B streptococcal infection. J. Infect. Dis. 166:635-639.
26. Avery, O. T., and W. F. Goebel. 1931. Chemo-immunological studies on conjugated carbohydrate-proteins. V. The immunological specificity of an antigen prepared by combining the capsular polysaccharide of type III pneumococcus with foreign protein. J. Exp. Med. 54:437-447.

27. Decker, M. D., K. M. Edwards, R. Bradley, and P. Palmer. 1993. Responses of children to booster immunization with their primary conjugate Haemophilus influenzae type B vaccine or with polyribosylribitol phosphate conjugated with diphtheria toxoid. J. Pediatr. 122:410-413.

28. Schutze, M.-P., C. Leclerc, M. Jolivet, F. Audibert, and L. Chedid. 1985. Carrier-induced epitopic suppression, a major issue for future synthetic vaccines. J. Immunol. 135:2319-2322.

29. Schutze, M. P., C. Leclerc, F. R. Vogel, and L. Chedid. 1987. Epitopic suppression in synthetic vaccine models: analysis of the effector mechanisms. Cell. Immunol. 104:79-90.

30. Paoletti, L. C., D. L. Kasper, F. Michon, J. DiFabio, K. Holme, H. J. Jennings, and M. R. Wessels. 1990. An oligosaccharide-tetanus toxoid conjugate vaccine against type III group B Streptococcus. J. Biol. Chem. 265:18278-18283.

31. Kasper, D. L., D. K. Goroff, and C. J. Baker. 1978. Immunochemical characterization of native polysaccharides from group B streptococcus: the relationship of the type III and group B determinants. J. Immunol. 121:1096-1105.

32. Stalhammar, C. M., L. Stenberg, and G. Lindahl. 1993. Protein rib: a novel group B streptococcal cell surface protein that confers protective immunity and is expressed by most strains causing invasive infections. J. Exp. Med. 177:1593-1603.

33. Linden, V., K. K. Christensen, and P. Christensen. 1983. Correlation between low levels of maternal IgG antibodies to $\mathrm{R}$ protein and neonatal septicemia with group B streptococci carrying R protein. Int. Arch. Allergy Appl. Immunol. 71:168-172.

34. Flores, A. E., and P. Ferrieri. 1989. Molecular species of R-protein antigens produced by clinical isolates of group B streptococci. J. Clin. Microbiol. 27:10501054

35. Schwartz, B. A., and G. R. Gray. 1977. Proteins containing reductively aminated disaccharides. Synthesis and chemical characterization. Arch. Biochem. Biophys. 181:542-549.

36. Lindahl, G., B. Akerstrom, J. P. Vaerman, and L. Stenberg. 1990. Characterization of an IgA receptor from group B streptococci: specificity for serum IgA. Eur. J. Immunol. 20:2241-2247.

37. Heden, L. O., E. Frithz, and G. Lindahl. 1991. Molecular characterization of an $\mathrm{IgA}$ receptor from group $\mathrm{B}$ streptococci: sequence of the gene, identification of a proline-rich region with unique structure and isolation of $\mathrm{N}$-terminal fragments with IgA-binding capacity. Eur. J. Immunol. 21:1481-1490.

38. Flores, A. E., J. A. Nelson, X. Y. Wu, and P. Ferrieri. 1993. Antibody profiles to the group B streptococcal beta antigen in maternal and infant paired sera. APMIS (Acta Pathol. Microbiol. Immunol. Scand.). 101:41-49.

39. Brady, L. J. and M. D. Boyle. 1989. Identification of non-immunoglobulin A-Fc-binding forms and low-molecular-weight secreted forms of the group B streptococcal beta antigen. Infect. Immun. 57:1573-1581. 